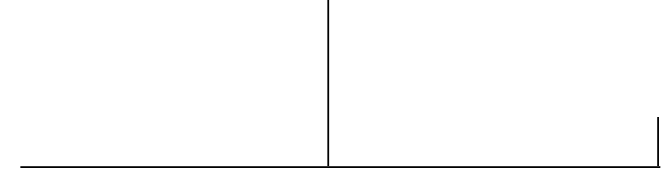

Rev. Latinoam. Psicopat. Fund., São Paulo, v. 11, n. 2, p. 265-266, junho 2008

\title{
Risco de suicídio é preocupação de agência dos EUA nos testes clínicos de drogas contra obesidade; gordos resistem a emagrecer, conta artigo
}

Mônica Teixeira

O texto que publicamos nesta edição de "Observando a Medicina" apareceu na Business Week, a revista semanal norte-americana de economia, no dia 6 de março de 2007. A reportagem, escrita por Arlene Weintraub, competente jornalista de ciência e tecnologia da revista, relata os esforços de empresas do setor farmacêutico que desenvolvem drogas contra obesidade para chegar até um medicamento que emagreça e não cause efeitos colaterais o mais temido entre eles, no momento, sendo o suicídio. Weintraub visitou empresas, ouviu seus executivos e pesquisadores; também procurou cientistas das universidades. $\mathrm{O}$ resultado do trabalho mostra o quanto engordar - e emagrecer - guarda um caráter quase inexpugnável para os esforços da indústria farmacêutica. Entre as vicissitudes a enfrentar, há o fato de o cérebro dos gordos, segundo conta um pesquisador à jornalista, resistir à perda de peso aumentando a fome de quem emagrece e tornando mais lento seu metabolismo; e a tendência das drogas em teste atualmente - inclusive uma "outrora promissora", do laboratório Sanofi Aventis - de levarem voluntários ao suicídio. 
Em informações dispostas ao lado da reportagem, a revista reuniu dados impressionantes sobre o aumento do peso dos norte americanos. Em 1996, afirma a revista, nem um Estado norte-americano tinha mais de 19\% de seus habitantes com 13 quilos ou mais de sobrepeso. Em 2006, todos os Estados do país, menos três, tinham mais de $20 \%$ de seus habitantes com os 13 quilos ou mais de sobrepeso; em dois deles, essa percentagem era superior a $30 \%$. O problema avança. A comida é barata para quem mora no país mais poderoso do mundo. E, a julgar pelas dificuldades da indústria farmacêutica e de biotecnologia, a solução não está em uma pílula.

\section{Mônica Teixeira}

Jornalista; psicanalista; coordenadora geral do programa Universidade Virtual do Estado de São Paulo na TV Cultura (São Paulo, SP, Brasil); diretora de redação do boletim eletrônico Inovação Unicamp (Campinas, SP, Brasil).

Av. Higienópolis, 318/13

01238-001 São Paulo, SP, Brasil

e-mail: armonica@uol.com.br 